\title{
Hubungan Lamanya Terapi ARV dengan Kepatuhan Minum Obat pada Anak HIV di Klinik Teratai
}

\author{
Ari Haryatiningsih ${ }^{1}$, Anggraini Alam², Trully Deti Rose Sitorus ${ }^{3}$ \\ ${ }^{1}$ Fakultas Kedokteran, Universitas Padjadjaran \\ ${ }^{2}$ Departemen Ilmu Kesehatan Anak, Fakultas Kedokteran Universitas Padjadjaran/ \\ Rumah Sakit Umum Pusat Dr. Hasan Sadikin, Bandung \\ ${ }^{3}$ Departemen Farmakologi dan Terapi, Fakultas Kedokteran Universitas Padjadjaran/ \\ Rumah Sakit Umum Pusat Dr. Hasan Sadikin, Bandung
}

\begin{abstract}
Abstrak
Prevalensi Human Immunodeficiency Virus (HIV) di Indonesia mengalami peningkatan. Manajemen utama penderita HIV adalah dengan memberi obat antiretroviral (ARV) untuk seumur hidup. Kepatuhan adalah faktor yang paling penting dalam keberhasilan terapi ARV. Penelitian ini bertujuan untuk mengetahui Hubungan Lamanya Terapi ARV dengan Kepatuhan Minum Obat pada Anak HIV di Klinik Teratai-RSHS. Penelitian menggunakan studi desain analitik Cross sectional, data diambil dari bulan November - Desember 2016 secara retrospektif dari kartu pengobatan pasien anak yang terdiagnosis HIV dan mengambil obat di Klinik TerataiRSHS , Bandung. Jumlah sampel minimal 33. Pasien HIV anak lebih banyak pada umur $\leq 5$ tahun $(70,6 \%)$, jenis kelamin laki-laki $(64,7 \%)$ dan lamanya terapi $13-18$ bulan $(23,5 \%)$ dan $19-24$ bulan $(23,5 \%)$. Pasien HIV anak dengan lama terapi $13-18$ bulan tingkat kepatuhannya rendah $<95 \%$, sedangkan lama terapi $\leq 6$ bulan tingkat kepatuhannya baik $\geq 95 \%$. Hasil analisis korelasi diperoleh tidak ada Hubungan antara lamanya terapi dengan kepatuhan minum obat $\operatorname{ARV}(p=0,94 ; r=-0,292)$. Dari penelitian ini didapatkan bahwa tidak adanya hubungan antara lamanya terapi dengan kepatuhan minum obat ARV pada pasien HIV di Klinik Teratai.
\end{abstract}

Kata Kunci : ARV, HIV pada Anak, Kepatuhan

\section{Correlation Between Duration of Antiretroviral (ARV) Therapy and Drug Adherence in Children with HIV}

\begin{abstract}
Prevalence of children with Human immunodeficiency virus (HIV) in Indonesia is increasing. The ultimate management of HIV patient is by taking antiretroviral (ARV) medication for a lifetime. Adherence is the most important factor in determining ARV therapy efficacy. This study aimed to determine the correlation between ARV therapy duration and drug adherence in children with HIV at Teratai Clinic. An analytical cross sectional study was conducted from November to December 2016. Data in this study was obtained retrospectively from medical record of child patient diagnosed with HIV whom taking drugs from Teratai Clinic-RSHS, Bandung. A minimum sample amount of 33. The number of child patient with HIV is higher in $\leq 5$ year age $(70,6 \%)$, male gender $(64,7 \%)$, and therapy duration of 13-18 month $(23,5 \%)$ and $19-24$ month $(23,5 \%)$. HIV positive child patient with 13-18 month duration of treatment has low adherence rates of $<95 \%$, whereas in whom duration of therapy $\leq 6$ month has higher adherence of $\geq 95 \%$. Correlation analysis test showed no association between duration of ARV therapy and drug adherence $(p=0,94 ; r=-0,292)$. There is no correlation between duration of ARV therapy and drug adherence in children with HIV at Teratai Clinic.
\end{abstract}

Keyword : Adherence, $A R V, H I V$

Korespondensi:

Ari Haryatiningsih

Fakultas Kedokteran, Universitas Padjadjaran

Jl. Raya Bandung-Sumedang km 21 Jatinangor

Mobile : 087827814270

Email : ariharyatiningsih@gmail.com 


\section{Pendahuluan}

Human Immunodeficiency Virus (HIV) adalah retrovirus yang dapat menginfeksi sel sistem kekebalan tubuh, menyebabkan sel sistem kekebalan tubuh akan hancur atau fungsinya rusak. Sistem kekebalan tubuh menjadi lemah maka akan lebih rentan terhadap berbagai penyakit infeksi. ${ }^{1}$ Di dunia tingkat infeksi HIV terus meningkat dengan estimasi 1.000 anak-anak yang baru terinfeksi HIV setiap hari pada tahun 2009, yang sebagian besar berasal dari negara yang terbatas sumber dayanya. ${ }^{2}$ Di Indonesia kasus HIV secara kumulatif mulai tahun 1987 hingga September 2014, jumlah penderita HIV sebanyak 150.296 orang. Berdasarkan data dari Komisi Penanggulangan HIV/AIDS Provinsi Jawa Barat, pada tahun 1989 sampai April 2013 dilaporkan bahwa terdapat 48.818 kasus HIV/ AIDS di Jawa Barat. ${ }^{3}$

Manajemen utama penderita HIV adalah dengan memberi obat antiretroviral (ARV). Kementerian Kesehatan Republik Indonesia telah mencatat jumlah penderita HIV yang menerima terapi ARV sampai dengan bulan September 2014 yaitu sebanyak 45.631 orang namun sekitar 15.046 orang penderita HIV sebagai pasien lost to follow-up. ${ }^{4}$ Pada tahun 2010 di Jawa Barat penderita HIV yang masih menerima terapi ARV yaitu sekitar 2.001 orang. ${ }^{5}$ Data di Klinik TerataiRSHS sampai dengan akhir Desember 2008 tercatat 496 penderita HIV anak yang menerima terapi ARV. ${ }^{6}$

Penggunaan obat ARV pada penderita HIV merupakan upaya untuk memperpanjang umur harapan hidup penderita HIV. Obat ARV bekerja memperlambat replikasi virus sehingga virus dalam sirkulasi darah menurun lalu meningkatkan CD4+ dan sistem imun meningkat. ${ }^{5}$ Faktor yang penting dalam keberhasilan terapi ARV adalah kepatuhan penderita HIV untuk meminum obat. Kepatuhan atau adherence pada terapi adalah suatu keadaan pasien sadar sendiri dan bukan semata-mata karena mematuhi perintah dokter untuk menjalani pengobatannya. ${ }^{7}$ Salah satu faktor penyebab rendahnya kepatuhan minum obat pada anak HIV adalah kejenuhan dan kebosanan baik care giver maupun anak HIV dalam minum obat ARV karena anak HIV harus meminum obat yang sama setiap hari dan tidak boleh ada yang terlewat selama seumur hidup. ${ }^{8}$ Diperlukan tingkat kepatuhan terapi ARV yang sangat tinggi dan efektif untuk terapi sebesar $95 \%$, maka dari itu minum obat harus tepat dosis, tepat waktu dan tepat caranya untuk mencapai tingkat supresi virus yang optimal. ${ }^{9}$ Mengingat demikian pentingnya kepatuhan minum obat bagi pasien HIV dengan terapi antiretroviral, maka perlu dilakukan penelitian tentang hubungan lamanya terapi ARV dengan kepatuhan minum obat pada anak HIV di Klinik Teratai-RSHS, Bandung.

\section{Metode}

Penelitian ini menggunakan studi desain analitik cross sectional yang dilakukan pada bulan November-Desember 2016 di Klinik TerataiRSHS, Bandung. Subjek penelitian adalah pasien anak yang terdiagnosis HIV dan mengambil obat di Klinik Teratai-RSHS, Bandung. Jumlah minimal sampel sebanyak 33 orang ditentukan berdasarkan rumus penelitian analitik kategorik tidak berpasangan untuk menaksir proporsi populasi.

Sebelum dilakukan pengambilan data dari kartu berobat pasien, aspek legalitas tetap diperhatikan dengan adanya sesuai surat kelayakan etik yang diterbitkan oleh Komite Etik Fakultas Kedokteran dengan nomor : 946/UN6. C1.3.2/KEPK/PN/2016 dan surat izin penelitian dari Bidang Pendidikan dan Penelitian Diklit dan Komite Etik Rumah Sakit Hasan Sadikin no 38, Bandung.

Pengumpulan data dimulai dengan memilih kartu berobat anak HIV di Klinik Teratai RSHS, Bandung. Kriteria inklusi pada penelitian ini adalah anak HIV yang mengambil obat antiretroviral di Klinik Teratai-RSHS Bandung, mulai pengobatan antiretroviral pada tahun 20132015 dan data jumlah tablet perbulan, jumlah tablet yang diminum atau sisa tablet yang di minum. Didapatkan jumlah sebanyak 11 subjek untuk tahun 2013, 17 subjek untuk tahun 2014 dan 6 subjek untuk tahun 2015 yang memiliki data lengkap serta memenuhi kriteria inklusi. Maka dari kriteria inklusi didapatkan jumlah subjek sebanyak 34 . Sedangkan untuk kriteria eksklusinya adalah data yang tidak lengkap.

Variabel yang dinilai dalam penelitian ini adalah kepatuhan minum obat sebagai variabel bebas dan lamanya terapi sebagai variabel terikat. Selain itu penelitian ini menilai karakteristik subjek yang terdiri dari usia $(\leq 5,6-10$ dan 11 $-<18$ ), jenis kelamin (laki-laki dan perempuan) dan lamanya terapi $(\leq 6,7-12,13-18,19-24,25-$ 30, dan 31-36). Data yang telah terkumpul selanjutnya dianalisis menggunakan metode uji chi-square dengan menggunakan piranti lunak SPSS. Selanjutnya dari hasil analisis akan di sajikan dalam bentuk tabel.

\section{Hasil}

Berdasarkan penelitian yang dilakukan pada 34 
subjek dengan cara melihat dari kartu pengobatan anak HIV di Klinik Teratai Rumah Sakit Dr. Hasan Sadikin, Bandung, maka diperoleh data sebagai berikut:

Tabel 1 Karakteristik Anak HIV di Klinik Teratai berdasarkan Jenis Kelamin dan Lamanya Terapi $(\mathbf{n}=34)$

\begin{tabular}{ccc}
\hline Karakteristik & Jumlah (n) & $\begin{array}{c}\text { Presentase } \\
(\mathbf{\%})\end{array}$ \\
\hline Usia & & \\
$\leq 5$ & 24 & 70,6 \\
$6-10$ & 8 & 23,5 \\
$11-<18$ & 2 & 5,9 \\
Jenis Kelamin & & \\
$\quad$ Laki-laki & 22 & 64,7 \\
Perempuan & 12 & 35,3 \\
Lama Terapi & & \\
$\leq 6$ & 1 & 2,9 \\
$7-12$ & 6 & 17,6 \\
$13-18$ & 8 & 23,5 \\
$19-24$ & 8 & 23,5 \\
$25-30$ & 7 & 20,6 \\
$31-36$ & 4 & 11,8 \\
\hline
\end{tabular}

Tabel 2 Presentase Kepatuhan Minum Obat ARV pada Anak HIV di Klinik Teratai

\begin{tabular}{|c|c|c|}
\hline \multirow{2}{*}{ Lamanya Terapi (Bulan) } & \multicolumn{2}{|c|}{ Kepatuhan n (\%) } \\
\hline & $<95 \%$ & $\geq 95 \%$ \\
\hline$\leq 6$ & $0(0)$ & $1(2,9)$ \\
\hline $7-12$ & $2(5,9)$ & $4(11,8)$ \\
\hline $13-18$ & $6(17,6)$ & $2(5,9)$ \\
\hline $19-24$ & $3(8,8)$ & $5(14,7)$ \\
\hline $25-30$ & $5(14,7)$ & $2(5,9)$ \\
\hline $31-36$ & $3(8,8)$ & $1(2,9)$ \\
\hline Total & $19(55,9)$ & $15(44,1)$ \\
\hline
\end{tabular}

Tabel 3 Hubungan Antara Lamanya Terapi dengan Kepatuhan Minum Obat ARV pada Anak HIV di Klinik Teratai

\begin{tabular}{lcc}
\hline \multirow{2}{*}{$\begin{array}{l}\text { Hubungan Lamanya Terapi ARV } \\
\text { dengan Kepatuhan Minum Obat }\end{array}$} & \multicolumn{2}{c}{ Statistik* } \\
\cline { 2 - 3 } pada Anak HIV di Klinik Teratai & 0,94 & $-0,292$ \\
\hline
\end{tabular}

Keterangan : ${ }^{*} \mathrm{Uji}$ chi-square, $\mathrm{r}=$ koefisien korelasi

Tabel 1 menunjukan karakteristik anak dengan HIV yang menjadi subjek pada penelitian ini berdasarkan usia, jenis kelamin dan lamanya terapi. Pada tabel tersebut didapat bahwa anak HIV lebih banyak pada usia $\leq 5$ tahun $(70,6 \%)$. Adapun untuk jenis kelamin adalah laki-laki $(64,7 \%)$. Sedangkan untuk lamanya terapi pada anak HIV yang paling banyak adalah 13-18 bulan $(23,5 \%)$ dan $19-24$ bulan $(23,5 \%)$.

Tabel 2 menunjukan presentase kepatuhan minum obat pada anak HIV di Klinik Teratai berdasarkan lamanya terapi. Pada tabel tersebut didapatkan bahwa kelompok anak HIV dengan tingkat kepatuhan tertinggi adalah kelompok lama terapi 19-24 bulan. Kelompok anak HIV dengan tingkat kepatuhan berobat terendah adalah kelompok lama terapi 7-12 bulan.

Tabel 3 menunjukan bahwa nilai $r=-0,292$ dan $\mathrm{p}=0,94$, kedua angka tersebut menyatakan bahwa tidak ada hubungan antara lamanya terapi dengan kepatuhan minum obat.

\section{Pembahasan}

Pada hasil penelitian ini didapatkan bahwa anak HIV di Klinik Teratai Rumah Sakit Hasan Sadikin, Bandung sebagian besar pada usia $\leq 5$ tahun dengan presentase 70,6\%. Hasil ini sesuai dengan laporan Ditjen PP \& PL Kemenkes RI tentang Statistik Kasus HIV/AIDS di Indonesia bahwa anak HIV paling banyak pada usia $\leq 5$ tahun Penularan dari ibu ke anak dapat terjadi sebelum (intrauterine) selama (intrapartum), atau setelah melahirkan (melalui menyusui). Pada trimester pertama jaringan plasenta dari wanita yang terinfeksi HIV telah terbukti mengandung HIV berdasarkan hibridisasi in situ dan imunohistokimia. Secara umum $30-$ $40 \%$ dari bayi yang baru lahir terinfeksi dalam kandungan, memiliki bukti laboratorium positif kultur virus atau Polymerase Chain Reaction (PCR) dalam minggu pertama kehidupan. ${ }^{2}$ Pada hasil penelitian ini juga didapat bahwa anak HIV sebagian besar adalah laki-laki dengan presentase $64,7 \%$. Hasilnya juga sesuai dengan laporan Ditjen PP \& PL Kemenkes RI tentang Statistik Kasus HIV/AIDS di Indonesia yang melaporkan bahwa anak laki-laki lebih banyak terkena HIV daripada anak perempuan. ${ }^{10}$

Lamanya terapi anak HIV berdasarkan hasil penelitian ini yang paling banyak adalah 13 18 bulan dan $19-24$ bulan dengan presentase yang sama yaitu $23,5 \%$.Hasil dari penelitian ini sesuai dengan data dari sebuah penelitian yang dilakukan oleh Velisitas V dan Linda T di Medan tahun 2012 dengan presentase $30,5 \%{ }^{11}$

Tingkat kepatuhan minum obat ARV pada anak HIV di Klinik Teratai Rumah Sakit Hasan Sadikin, Bandung berdasarkan lamanya terapi 
pada penelitian ini adalah kelompok anak HIV dengan tingkat kepatuhan tertinggi adalah kelompok lama terapi 19-24 bulan. Kelompok anak HIV dengan tingkat kepatuhan berobat terendah adalah kelompok lama terapi 7-12 bulan. Hasilnya sesuai dengan penelitian tentang Gambaran Kepatuhan Orang dengan HIV/ AIDS (ODHA) dalam minum obat ARV di kota Bandung, yang menyatakan bahwa adanya faktor-faktor yang dapat menghambat tingkat kepatuhan penderita HIV yang salah satunya adalah kejenuhan. Biasanya kejenuhan mulai terjadi bila penderita HIV sudah 6 bulan minum obat ARV karena penderita HIV harus setiap hari minum obat dan sudah merasa bosan atau sudah merasa sehat. Kurangnya tingkat kepatuhan pada anak HIV yang berobat $>7$ bulan bisa juga karena faktor-faktor penghambat lainnya seperti biaya berobat, efek samping obat, dan stigma dari lingkungan yang membuat sebagian besar penderita HIV merasa kurang nyaman. ${ }^{8}$

Berdasarkan hasil penelitian Hubungan Lamanya Terapi ARV dengan Kepatuhan Minum Obat pada anak HIV di Klinik Teratai, didapat bahwa nilai $\mathrm{p}=0,94$ dan $\mathrm{r}=-0,292$, maka dapat diambil kesimpulan bahwa tidak ada hubungan antara lamanya terapi ARV dengan kepatuhan minum obat. Hasil penelitian ini sesuai dengan hasil penelitian yang telah di lakukan oleh Walter E dan Soh E, di Cameroon. Hasil dari penelitiannya adalah tidak adanyahubungan antara lamanya terapi ARV dengan kepatuhan minum obat dengan nilai $\mathrm{p}=0,361 .{ }^{12}$

Berdasarkan hasil penelitian ini lama terapi 13-18 bulan tingkat kepatuhannya rendah $<95 \%$, sedangkan anak HIV dengan lama terapi $\leq 6$ bulan tingkat kepatuhannya baik $\geq 95 \%$. Berdasarkan hasil penelitian ini juga didapat nilai $p=0,94$ dan $r=0,292$, jadi penelitian ini tidak ada hubungan antara lamanya terapi dengan kepatuhan minum obat ARV pada anak HIV di Klinik Teratai.

Keterbatasan dari penelitian ini adalah ketidaklengkapan data di kartu berobat pasien HIV anak di Klinik Teratai. Berbagai penelitian sebelumnya tidak terdapat penelitian yang menyatakan tentang hubungan lamanya terapi ARV dengan kepatuhan minum obat pada anak HIV, banyaknya penelitian pada orang dewasa.

Sebaiknya dilakukan penelitian lebih lanjut dengan jumlah sampel lebih banyak dan dalam proses pengambilan sampel bisa dilakukan beberapa tahun ke belakang tidak hanya fokus pada satu sampai tiga tahun saja, agar dapat lebih akurat dalam menganalisa hasil. Dalam kartu berobat hendaknya tercatat lebih lengkap lagi dan di usahakan kartu berobat tidak hilang.

\section{Daftar Pustaka}

1. World Health Organization. HIV/AIDS. 2016.

2. Kliegman, Robert. Nelson WE. Nelson Textbook Of Pediatrics,19e. 1898-1997. $1-8976$

3. Ibrahim K, Eemliyawati E, Rahayu U NA. Prediktor kepatuhan minum obat Antiretroviral (ARV) pada orang hidup dengan HIV/AIDS (ODHA). 2013;1-47.

4. Infodatin AIDS. Pusat Data Dan Informasi Kementerian Keseharan RI. Situasi Dan Analisis HIV AIDS. 2014.

5. Yuniar Y, Handayani R A. Faktor-faktor Pendukung Kepatuhan Orang dengan HIV AIDS (ODHA) Dalam Minum Obat Antiretroviral Di Kota Bandung dan Cimahi. 2012;72-83.

6. Sumantri R, Supandiman I, Indjradinata P, Ven A Van Der. Immune Deficiency Syndrome berdasarkan Gabungan Derajat Anemia , Indeks Massa Tubuh, dan Jumlah Cluster Differentiation 4 Opportunity of Death in Human Immunodeficiency Virus-Acquired Immunodeficiency Syndrome Patients by Combining Degree of Anemia , Body Mass Index, and Cluster Differentiation 4 Count. 2008;44(1):50-6.

7. Shintawati I. Faktor Pendukung dan Penghambat Kepatuhan Penggunaan Obat: Studi Kualitatif Pada Pasien HIV/AIDS dengan Terapi Antiretroviral Lini Kedua di Provinsi D.I. Yogyakarta. 2014;

8. Sugiharti, Yuyun, Heny TP, Kesehatan BI, Litbangkes. Gambaran Kepatuhan Orang dengan HIV/AIDS (ODHA) dalam minum obat ARV di kota Bandung, Provinsi Jawa Barat ,tahun 2011-2012. 2014;1-11.

9. Ubra RR. Faktor-faktor yang Berhubungan dengan Kepatuhan Pengobatan Minum ARV Pada Pasien HIV Di Kabupaten Mimika Papua Tahun 2012. 2012;

10. Ditjen PP \& PL Kemenkes RI. Statistik Kasus HIV/AIDS di Indonesia. 2014;(September):794-6.

11. Velisitas V, Linda $T$ LA. Faktor-faktor yang Berhubungan dengan Kepatuhan ODHA (Orang Dengan HIV/AIDS) Dalam Menjalani Terapi Antiretroviral di RSU. Dr. Pirngadi Medan Tahun 2012. 2012;

12. Pefura-yone EW, Soh E, Pascal A, Dodo A, Kuaban C. Non-adherence to antiretroviral therapyin Yaounde : Prevalence, determinants and the concordance of two screening criteria. J Infect Public Health [Internet]. King Saud Bin Abdulaziz University for Health Sciences; 2013;6(4):307-15. 